\title{
Pelepasan Flavonoid Gendarusa vulgaris Nees dari Matriks Sediaan Param Fraksi Etanol 60\% dan Param Fasa Air
}

\author{
Engrid Juni Astuti \\ Program Studi Farmasi Fakultas Ilmu Kesehatan Universitas Muhammadiyah Malang
}

Alamat Korespondensi : geed_99@yahoo.com

\begin{abstract}
The aim of the research is to know the different release gendarusin A from the external tradisional dosage form named param $60 \%$ ethanol and param water phase. The release gendarusin A was detected using Transdermal Delivery System equipment and cellophane membrane. Other conditions: Phosphate buffer $\mathrm{pH} 6,0$ as a diffusion Liquid, temperature $37^{\circ} \mathrm{C} \pm 0,5^{\circ} \mathrm{C}$, sampling time 10, 20,30,40,50,60 minutes and sample were analysis by HPLC to get concentration of gendarusin A. The result shows that the release flux param at $60 \%$ ethanol fraction $=0,6065 \mu \mathrm{g} / \mathrm{cm}^{2} /$ minute $^{1 / 2}$ and flux param water phase $=0,3895 \mu \mathrm{g} / \mathrm{cm}^{2} / \mathrm{minute}^{1 / 2}$. It means that the release gendarusin A from param ethanol $60 \%$ fraction more rapid than param water phase. Release gendarusin A percentage from param $60 \%$ ethanol fraction is bigger than param water phase.
\end{abstract}

Key word: gendarusin A, param, ethanol phase, water phase

\begin{abstract}
ABSTRAK
Penelitian ini bertujuan untuk mengetahui perbedaan pelepasan gendarusin A dari sediaan tradisional eksternal yang disebut dengan param $60 \%$ ethanol dan param dalam fase air. Pelepasan gendarusin A dideteksi menggunakan perangkat Transdermal Delivery System dan membran selofan. Kondisi-kondisi yang ditetapkan antara lain larutan Buffer dengan $\mathrm{pH}$ 6,0 sebagai cairan difusi, temperatur $37 \mathrm{oC}+/-0,5 \mathrm{oC}$. Waktu sampling ditentukan 10, 20, 30, 40, 50 dan 60 menit dan sampel dianalisis menggunakan HPLC untuk mendapatkan konsentrasi gendarusin A. Disimpulkan bahwa pelepasan fluks param fraksi etanol $60 \%=0,6065 \mu \mathrm{g} / \mathrm{cm}^{2} / \mathrm{minute}^{1 / 2}$ dan fluks param fase air $0,3895 \mu \mathrm{g} / \mathrm{cm}^{2} /$ minute $^{1 / 2}$. Hal ini menunjukkan bahwa pelepasan gendarusin A dalam param fase ethanol $60 \%$ lebih cepat dibandingkan dengan param fase air. Persentase pelepasan gendarusin A dalam param fase etanol $60 \%$ lebi besar dibandingkan dengan param fase air.
\end{abstract}

Kata kunci: gendarusin A, param, fase etanol, fase air 


\section{PENDAHULUAN}

Tanaman Gendarussa vulgaris Nees dari hasil penelitian berguna sebagai analgesik antiinflamasi. Dan salah satu kandungan dari gendarusa adalah flavonoid.

Flavonoid merupakan salah satu golongan fenol alam yang terbesar dan terdapat dalam semua tanaman hijau. Dalam tumbuhan, aglikon flavonoid terdapat dalam berbagai struktur. Semuanya mengandung 15 atom karbon dalam inti dasarnya, yang tersusun dalam konfigurasi C6-C3-C6, yaitu dua cincin aromatik yang dihubungkan oleh tiga karbon yang dapat atau tak dapat membentuk cincin ketiga. (Markham, 1988). Isolasi flavonoid gendarusa mengandung flavonol-3-glikosida (Prajogo \& suwijiyo, 1988). Dalam fraksi n-butanol pada LC-MS diketahui ada 12 komponen dengan berat molekul sama serta hanya dapat diisolasi 2 komponen flavonoid major dan minor. Komponen major adalah gendarusin A dan komponen minor adalah gendarusin $\mathrm{B}$ (Prajogo, 2002). Kedua komponen itu termasuk dalam golongan flavonoid apigenin dimana apigenin memiliki efek sebagai antiinflamasi (Harbone, dkk,1999).

Sediaan topikal dikatakan efektif apabila zat aktif dapat mencapai tempat kerja (side of action) dalam jumlah yang sesuai dan dalam waktu yang diharapkan (Leons, 1988). Untuk mewujudkan adanya sediaan topikal bentuk param dengan zat aktif yang efektif, perlu dilakukan penelitian uji pelepasan dari pembawanya. Param gandarusa ini terdiri dari fraksi etanol $60 \%$ dan fasa air yang masing-masing berfungsi sebagai bahan baku, Amylum orizae sebagai pembawa, dan bahan aktif yang diharapkan keluar dari pembawanya adalah flavonoid major pada gendarusa yaitu Gendarusin A. Uji pelepasan dari matriksnya dapat dilakukan secara in vitro dengan dibatasi membran atau tidak (Barry, 1983). Pada penelitian ini akan menggunakan membran selulosa asetat (selofan) yang merupakan membran porus. Jumlah Gendarusin A yang dapat melewati membran menggambarkan besarnya Gendarusin A yang dapat dilepaskan dari matriksnya.

\section{METODOLOGI PENELITIAN}

\section{Penyiapan Bahan Tanaman Untuk} Ekstrak

Daun Gendarussa vulgaris Ness dalam keadaan segar dikeringkan di udara terbuka dengan sinar matahari tidak langsung. Setelah kering digiling, diayak sampai derajat halus 30 mikron.

\section{Pembuatan Fraksi Etanol dan Fasa Air}

Serbuk ditimbang sebanyak 4,67 kg, kemudian dimaserasi dengan n-Heksan sebanyak 10 liter dan diaduk selama 12 jam, kemudian ekstrak ditampung. Setiap kali penampungan pelarut n-Heksan ditambahkan dengan jumlah yang sama seperti maserasi pertama. Maserasi dilakukan selama 3 hari berturut-turut sehingga total n-Heksan yang dipakai 30 liter. Ekstraksi dengan n-Heksan untuk memisahkan kandungan lemak dan klorofil dari daun gendarusa.

Pada hari terakhir penampungan residu hasil maserasi dikeringkan dalam lemari asam sampai pelarut heksan yang tersisa menguap. Residu yang telah kering dimaserasi kembali dengan cara yang sama denga menggunakan pelarut etanol $60 \%$ sebanyak 10 liter sehingga total etanol $60 \%$ yang dipakai 30 liter. Fraksi etanol 60\% yang didapat diuapkan dengan rotavapour sampai terbentuk massa kental.

Ekstrak kental tersebut kemudian diencerkan dengan aquadest samapi larut dengan perbandingan $1: 3$ dan diasamkan 
dengan $\mathrm{HCl} 2 \mathrm{~N}$ sampai diperoleh $\mathrm{pH} 3-4$, kemudian ekstrak cair tersebut dipartisi dengan kloroform sama banyak didalam corong pisah. Partisi dilakukan sebanyak 3 kali dan diambil fasa airnya. Fasa air yang didapat dibasakan dengan $\mathrm{NH}_{4} \mathrm{OH} 25 \%$ sampai diperoleh pH 9-10, kemudian dipartisi dengan kloroform sama banyak dan dilakukan 3 kali. Dari proses partisi diambil fasa airnya.

\section{Penentuan Kondisi Kromatografi}

Pada penelitian ini digunakan seperangkat HPLC yang terdiri dari :

1. Liquid chromatograph (LC-10AT)

2. Communication Bus module (CMB10AV)

3. Column oven (CTO-10AC)

4. UV VIS Detector (SPD-10AV)

5. Kolom Nova-Pak ${ }^{\circledR} \mathrm{C} 18$ dengan ukuran 3,9x150 mm, adalah kolom fase balik (reverse phase), karena kolom ini sangat baik digunakan untuk komponen yang bersifat polar.

Kondisi yang digunakan pada HPLC adalah

1. Aliran (flow) fase mobile $1 \mathrm{ml} /$ menit

2. Stop time 25 menit

3. Tekanan maksimum 300 bar

4. Panjang gelombang (ë) $254 \mathrm{~nm}$

\section{Fase Mobil}

Fase mobil digunakan metanol : air (30 : 70) karena flavonoid larut dalam air maupun metanol

\section{Pembuatan Larutan Dapar Fosfat 0,01 M pH 6,0}

Dapar fosfat $0,01 \mathrm{M} \mathrm{pH} \mathrm{6,0} \mathrm{dibuat}$ denga cara sebanyak 0,7342 gram $\mathrm{NaH}_{2} \mathrm{PO}_{4} \cdot 2 \mathrm{H}_{2} \mathrm{O}$ dimasukkan dalam labu ukur 500,0 ml, kemudian ditambah dengan
0,1039 gram $\mathrm{NaHPO}_{4} \cdot 12 \mathrm{H}_{2} \mathrm{O}$. Campuran dilarutkan dengan air bebas $\mathrm{CO}_{2}$ sampai garis batas. Larutan yang diperoleh diukur pHnya dengan $\mathrm{pH}$ meter. Bila $\mathrm{pH}$ yang diperoleh lebih kecil dari 6,0 maka larutan tersebut ditambah larutan $\mathrm{Na}_{2} \mathrm{HPO}_{4} .12$ $\mathrm{H}_{2} \mathrm{O}$, jika $\mathrm{pH}$ yang diperoleh lebih besar dari 6,0 maka larutan ditambah dengan larutan $\mathrm{NaH}_{2} \mathrm{PO}_{4} \cdot 2 \mathrm{H}_{2} \mathrm{O}$ sampai larutan mencapai pH 6,0.

\section{Pembuatan Kurva Baku Gendarusin A}

Larutan standar Gendarusin Adibuat dengan mengencerkan standar Gendarusin A 200 $\mu \mathrm{g} / \mathrm{ml}$ dalam larutan dapar fosfat $\mathrm{pH} 6,0$ sehingga diperoleh larutan standar gendarusin A kadar 2,$5 ; 5 ; 10 ; 20 ; 40 \mu \mathrm{g} /$ $\mathrm{ml}$, saring dengan membran milipore $0,2 \mu \mathrm{l}$ kemudian disuntikkan ke HPLC sebanyak $20 \mu$ l. Selanjutnya dibuat hubungan antara kadar dengan luas area. Dan dibuat persamaan regresinya.

\section{Penetapan kadar Gendarusin A Dalam Fraksi Etanol Dan Fasa Air}

$5 \mathrm{mg}$ fraksi etanol $60 \%$ dan $50 \mathrm{mg}$ fasa air masing-masing di larutkan dengan larutan dapar pH 6,0 dalam labu ukur 5 ml, kemudian saring dengan membran milipore $0,2 \mu 1$ dan suntikkan $20 \mu 1$ ke dalam HPLC. Luas area yang didapat dimasukkan ke persamaan regresi kurva baku dan diperoleh kadar.

\section{Preparasi Sediaan Param}

Dari hasil penelitian pendahuluan Reza (2004) didapatkan batas kuantitasi (limit of quantitation / LOQ) sebesar 0,4636 $\mu \mathrm{g} / \mathrm{ml}$. Untuk itu dibuat sediaan param dimana hasil pelepasan gendarusin A dari param Fraksi etanol $60 \%$ dan param fasa air lebih besar dari LOQ.

Komposisi param sebagai berikut : 
R/ Fraksi etanol 60\% / Fasa Air

$2,85 \mathrm{~g}$

$$
\text { Amylum orizae } \quad 0,15 \mathrm{~g}
$$

Cara pembuatan :

Amylum orizae dicampur dengan fraksi etanol / fasa air gerus sampai homogen

\section{Pemeriksaan pH Sediaan}

Ditimbang sebanyak 1 gram sediaan param kemudian diencerkan dengan aqua bebas $\mathrm{CO}_{2}$ ad $10 \mathrm{ml}$, kemudian diukur pHnya dengan $\mathrm{pH}$ meter.

Cara : Elektrode dicuci dengan aqua, bilas dan keringkan kalibrasi dengan larutan dapar pH 7,0 bilas dengan aqua dan keringkan. Kemudian masukkan elektroda dalam sediaan. Catat angka yang ditunjukkan oleh $\mathrm{pH}$ meter.

\section{Tahapan Uji Pelepasan}

2-3 gram sediaan ditimbang pada gelas arloji yang telah ditara kemudian masukkan dalam disk yang sudah dilengkapi dengan membran selofan yang telah direndam semalam dengan aquadest. Timbang sisa sediaan pada gelas arloji tersebut. Selisih berat merupakan sediaan uji. Bejana disolusi diisi dengan larutan dapar fosfat $\mathrm{pH}$ 6,0 sebanyak 350 $\mathrm{ml}$. Disk dimasukkan tabung disolusi dengan suhu diatur $37^{\circ} \mathrm{C} \pm 0,5^{\circ} \mathrm{C}$ kemudian larutan diaduk dengan kecepatan $100 \mathrm{rpm}$. Larutan cuplikan dipipet $5 \mathrm{ml}$ pada waktu 10, 20, 30, 40, 50 dan 60 menit. Setiap pengamilan cuplikan diganti media sebanyak $5 \mathrm{ml}$. Cuplikan dilakukan metode penetapan kadar Gendarusin A dengan HPLC.

\section{Analisis Data}

1. Kadar Gendarusin A yang dilepaskan setiap waktu ditentukan dari sampel (cuplikan) dengan HPLC. Kadar sampel didapat dari luas area sampel dimasukkan ke persamaan regresi kurva baku standar. Penentuan jumlah kumulatif flavonoid yang dilepas dari basis persatuan luas membran setiap waktu $(\mu \mathrm{g} / \mathrm{ml})$ dihitung dari kadar yang diperoleh setiap waktu $(\mu \mathrm{g} / \mathrm{ml})$ dikalikan dengan jumlah media $(350 \mathrm{ml})$ dan dibagi luas permukaan membran. Kemudian dibuat kurva hubungan antara jumlah kumulatif flavonoid yang dilepas $\left(\mu \mathrm{g} / \mathrm{cm}^{2}\right)$ terhadap (waktu) ${ }^{1 / 2}$.

2. Dari kurva yang dihasilkan dapat dihitung satu persamaan regresi. Berdasarkan persamaan Higuchi, slope dari persamaan regresi merupakan kecepatan pelepasan (fluks) flavonoid dari basis.

3. Prosentase pelepasan Gendarusin A dihitung dari kadar yang didapat dari tiap sampel dibagi dengan kadar mula-mula dan dikalikan seratus persen. Prosentase pelepasan Gendarusin a dihitung untuk mengetahui manakah yang memberikan pelepasan Gendarusin A terbesar antara param fraksi etanol $60 \%$ dengan param fasa air.

\section{HASIL DAN PEMBAHASAN}

Pembuatan Fraksi Etanol 60\% dan Fasa Air

Proses pembuatan fraksi etanol dan fasa air tertera pada Tabel 1 .

\section{Pembuatan Kurva Baku}

Kurva baku dibuat dari standar Gendarusin A $200 \mu \mathrm{g} / \mathrm{ml}$ dengan kadar 2,5; $5 ; 10 ; 20 ; 40 \mu \mathrm{g} / \mathrm{ml}$ kemudian diamati pada panjang gelombang $254 \mathrm{~nm}$ dengan HPLC. (Tabel 2).

\section{Penetapan Kadar Gendarusin A Dalam Fraksi Etanol 60\% dan Fasa Air}

Penetapan kadar dilakukan dengan melarutkan sejumlah bahan dengan larutan dapar fosfat $\mathrm{pH}$ 6,0 sampai $5 \mathrm{ml}$ dan di dapat 
Tabel 1. Berat Fraksi Etanol 60\% dan Fasa Air

\begin{tabular}{cccc}
\hline $\begin{array}{c}\text { Berat Serbuk } \\
\text { Daun }\end{array}$ & $\begin{array}{c}\text { Berat fraksi } \\
\text { Etanol } 60 \%\end{array}$ & $\begin{array}{c}\text { Berat Fraksi } \\
\text { Etanol } 605 \text { untuk } \\
\text { Fasa Air }\end{array}$ & Berat Fasa Air \\
\hline $4,67 \mathrm{~kg}$ & $1007 \mathrm{~g}$ & $370 \mathrm{~g}$ & $141 \mathrm{~g}$ \\
\hline
\end{tabular}

Tabel 2. Area Standar Gendarusin A Dalam Lanutan Dapar Fosfat $\mathrm{pH} 6,0$

\begin{tabular}{cc}
\hline Kadar $(\mu \mathrm{g} / \mathrm{ml})(\mathrm{X})$ & Area $(\mathrm{Y})$ \\
\hline 2,5 & 83093 \\
5 & 131155 \\
10 & 244412 \\
20 & 433694 \\
40 & 1292277 \\
\hline
\end{tabular}

Tabel 3. Penetapan Kadar Gendarusin A Dalam Fraksi Etanol 60\%

\begin{tabular}{ccccccc}
\hline Replikasi & $\begin{array}{c}\text { Penimbangan } \\
\text { Bahan (g) }\end{array}$ & Rerata (g) & Area & $\begin{array}{c}\text { Kadar } \\
\text { Gendarusin } \\
\mathrm{A}(\mathrm{ppm})\end{array}$ & Rerata (ppm) & KV (\%) \\
\hline 1 & 0,0050 & $0,0051 \pm$ & 223721 & 8,8487 & $8,9933 \pm$ & 2,27 \\
2 & 0,0052 & 0,0001 & 232994 & 9,1379 & 0,2045 & \\
\hline
\end{tabular}

Jadi dalam $1 \mathrm{mg}$ fraksi etanol $60 \%$ mengandung gendarusin A sebanyak 8,8169 $\mu \mathrm{g}$.

Tabel 4. Penetapan Kadar Gendarusin A dalam Fasa Air

\begin{tabular}{ccccccc}
\hline Replikasi & $\begin{array}{c}\text { Penimbangan } \\
\text { Bahan (g) }\end{array}$ & Rerata (g) & Area & $\begin{array}{c}\text { Kadar } \\
\text { Gendarusin } \\
\text { A (ppm) }\end{array}$ & Rerata (ppm) & KV (\%) \\
\hline 1 & 0,0500 & $0,0502 \pm$ & 2617234 & 83,5185 & $89,1332 \pm$ & 5,46 \\
2 & 0,0504 & 0,0002 & 2888885 & 91,9931 & 4,8627 & \\
3 & 0,0501 & 2885513 & 91,8879 & & \\
\hline
\end{tabular}

Jadi dalam $1 \mathrm{mg}$ fasa air mengandung gendarussin A sebanyak 8,8837 1/4g.

Tabel 5. pH Sediaan Param

\begin{tabular}{cccc}
\hline Param & Replikasi & $\mathrm{pH}$ & Rerata \\
\hline \multirow{2}{*}{ Fraksi Etanol $60 \%$} & 1 & 7,36 & $7,39 \pm 0,04$ \\
& 2 & 7,42 & \\
Fasa Air & 1 & 6,55 & $6,53 \pm 0,03$ \\
\hline
\end{tabular}

Tabel 6. Hasil Penimbangan Param Fraksi Etanol 60\%

\begin{tabular}{cccc}
\hline Replikasi & Berat Param $(\mathrm{g})$ & Berat Fraksi Etanol 60\% $(\mathrm{g})$ & Kadar awal gendarusin A $(\mu \mathrm{g})$ \\
\hline 1 & 3,0016 & 2,7003 & 23808,2751 \\
2 & 3,0006 & 2,6882 & 23701,5906 \\
\hline
\end{tabular}

Tabel 7. Kadar Hasil Pelepasan Gendarusin A Fraksi Etanol 60\% Replikasi 1

\begin{tabular}{cccccc}
\hline $\begin{array}{c}\text { Waktu } \\
\text { (menit) }\end{array}$ & $\mathrm{t} \mathrm{1} / 2$ (menit) $^{\text {Anea }}$ & Arear & $\begin{array}{c}\text { Kadar Gendarusin A } \\
(\mathrm{ppm})\end{array}$ & $\mathrm{Q}\left(\mu \mathrm{g} / \mathrm{cm}^{2}\right)$ & $\begin{array}{c}\text { Pelepasan } \\
\text { Gendarusin A (\%) }\end{array}$ \\
\hline 10 & 5 & 2926 & 1,9606 & 103,9421 & 2,88 \\
20 & 10 & 4562 & 2,0116 & 106,6459 & 2,96 \\
30 & 15 & 6173 & 2,0619 & 109,3125 & 3,03 \\
40 & 20 & 7902 & 2,1158 & 112,1701 & 3,11 \\
50 & 25 & 9538 & 2,1669 & 114,8792 & 3,19 \\
60 & 30 & 9413 & 2,1629 & 114,6671 & 3,18 \\
\hline
\end{tabular}


Tabel 8. Kadar Hasil Pelepasan Gendarusin A Fraksi Etanol 60\% Replikasi 2

\begin{tabular}{cccccc}
\hline $\begin{array}{c}\text { Waktu } \\
\text { (menit) }\end{array}$ & $\mathrm{t} 1 / 2$ (menit) & Area & $\begin{array}{c}\text { Kadar Gendarusin A } \\
(\mathrm{ppm})\end{array}$ & $\mathrm{Q}\left(\mu \mathrm{g} / \mathrm{cm}^{2}\right)$ & $\begin{array}{c}\text { Pelepasan } \\
\text { Gendarusin A (\%) }\end{array}$ \\
\hline 10 & 5 & 6309 & 2,0661 & 109,5352 & 3,05 \\
20 & 10 & 10034 & 2,1824 & 115,7009 & 3,22 \\
30 & 15 & 10800 & 2,2063 & 116,9679 & 3,26 \\
40 & 20 & 12291 & 2,2528 & 119,4332 & 3,33 \\
50 & 25 & 15231 & 2,3445 & 124,2947 & 3,46 \\
60 & 30 & 16067 & 2,3706 & 125,6784 & 3,50 \\
\hline
\end{tabular}

Tabel 9. Hasil Penimbangan Param Fraksi Air

\begin{tabular}{cccc}
\hline Replikasi & Berat Param $(\mathrm{g})$ & Berat Fraksi Air $(\mathrm{g})$ & Kadar awal gendarusin A $(\mu \mathrm{g})$ \\
\hline 1 & 3,0020 & 2,7111 & 24084,5991 \\
2 & 3,0019 & 2,7236 & 24195,6453 \\
\hline
\end{tabular}

Tabel 10. Kadar Hasil Pelepasan Gendarusin A Fraksi Air Replikasi 1

\begin{tabular}{cccccc}
\hline $\begin{array}{c}\text { Waktu } \\
\text { (menit) }\end{array}$ & $\mathrm{t} 1 / 2$ (menit) & Area & $\begin{array}{c}\text { Kadar Gendarusin A } \\
(\mathrm{ppm})\end{array}$ & $\mathrm{Q}\left(\mu \mathrm{g} / \mathrm{cm}^{2}\right)$ & $\begin{array}{c}\text { Pelepasan } \\
\text { Gendarusin A (\%) }\end{array}$ \\
\hline 10 & 5 & 5572 & 2,0430 & 108,3105 & 2,97 \\
20 & 10 & 5806 & 2,0505 & 108,7082 & 2,98 \\
30 & 15 & 6362 & 2,0678 & 109,6253 & 3,00 \\
40 & 20 & 7127 & 2,0917 & 110,8924 & 3,04 \\
50 & 25 & 7578 & 2,1057 & 111,6346 & 3,06 \\
60 & 30 & 8446 & 2,1328 & 113,0713 & 3,09 \\
\hline
\end{tabular}

Tabel 11. Kadar Hasil Pelepasan Gendarusin A Fraksi Air Replikasi 2

\begin{tabular}{cccccc}
\hline $\begin{array}{c}\text { Waktu } \\
\text { (menit) }\end{array}$ & $\mathrm{t}^{1 / 2 \text { (menit) }}$ & Area & $\begin{array}{c}\text { Kadar Gendarusin A } \\
(\mathrm{ppm})\end{array}$ & $\mathrm{Q}\left(\mu \mathrm{g} / \mathrm{cm}^{2}\right)$ & $\begin{array}{c}\text { Pelepasan } \\
\text { Gendarusin A (\%) }\end{array}$ \\
\hline 10 & 5 & 5989 & 2,0562 & 109,0104 & 2,97 \\
20 & 10 & 8402 & 2,1314 & 112,9971 & 3,08 \\
30 & 15 & 10252 & 2,1892 & 116,0614 & 3,17 \\
40 & 20 & 12034 & 2,2447 & 119,0038 & 3,25 \\
50 & 25 & 13278 & 2,2836 & 121,0661 & 3,30 \\
60 & 30 & 10102 & 2,1815 & 115,6532 & 3,16 \\
\hline
\end{tabular}

Tabel 12. Fluks Pelepasan Gendarusin A Dalam Param Fraksi Etanol 60\% dan Fasa Air

\begin{tabular}{lccc}
\hline \multicolumn{1}{c}{ Jenis Param } & Replikasi & $\begin{array}{c}\text { Fluks Pelepasan } \\
\left(\mu \mathrm{g} / \mathrm{cm}^{2} / \mathrm{menit}^{1 / 5}\right)\end{array}$ & $\begin{array}{c}\text { Rata-Rata Fluks } \\
\left(\mu \mathrm{\mu g} / \mathrm{cm}^{2} / \mathrm{menit}^{1 / 5}\right)\end{array}$ \\
\hline Fraksi Etanol $60 \%$ & 1 & 0,5479 & 0,6065 \\
Fasa Air & 2 & 0,6650 & 0,3895 \\
\hline
\end{tabular}


Tabel 13. Prosentase Pelepasan Gendarusin A Dari Param fraksi Etanol 60\% dan Param Fasa Air

\begin{tabular}{cccccc}
\hline Menit & Replikasi & $\begin{array}{c}\text { Pelepasan Gendarusin A (\%) } \\
\text { Param Fraksi } \\
\text { Etanol 60\% }\end{array}$ & $\begin{array}{c}\text { Param Fasa Air } \\
\text { Param Fraksi }\end{array}$ & $\begin{array}{c}\text { Pelepasan (\%) } \\
\text { Param Fasa Air }\end{array}$ \\
\hline 10 & 1 & 2,88 & 2,97 & $2,97 \pm 0,12$ & $2,97 \pm 0,00$ \\
& 2 & 3,05 & 2,97 & & \\
20 & 1 & 2,96 & 2,98 & $3,09 \pm 0,18$ & $3,03 \pm 0,07$ \\
& 2 & 3,22 & 3,08 & & \\
30 & 1 & 3,03 & 3,00 & $3,15 \pm 0,16$ & $3,09 \pm 0,12$ \\
& 2 & 3,26 & 3,17 & & \\
40 & 1 & 3,11 & 3,04 & $3,22 \pm 0,16$ & $3,15 \pm 0,15$ \\
& 2 & 3,33 & 3,25 & & \\
50 & 1 & 3,19 & 3,06 & $3,33 \pm 0,19$ & $3,18 \pm 0,17$ \\
& 2 & 3,46 & 3,30 & & \\
60 & 1 & 3,18 & 3,09 & $3,34 \pm 0,23$ & $3,13 \pm 0,05$ \\
& 2 & 3,50 & 3,16 & & \\
\hline
\end{tabular}

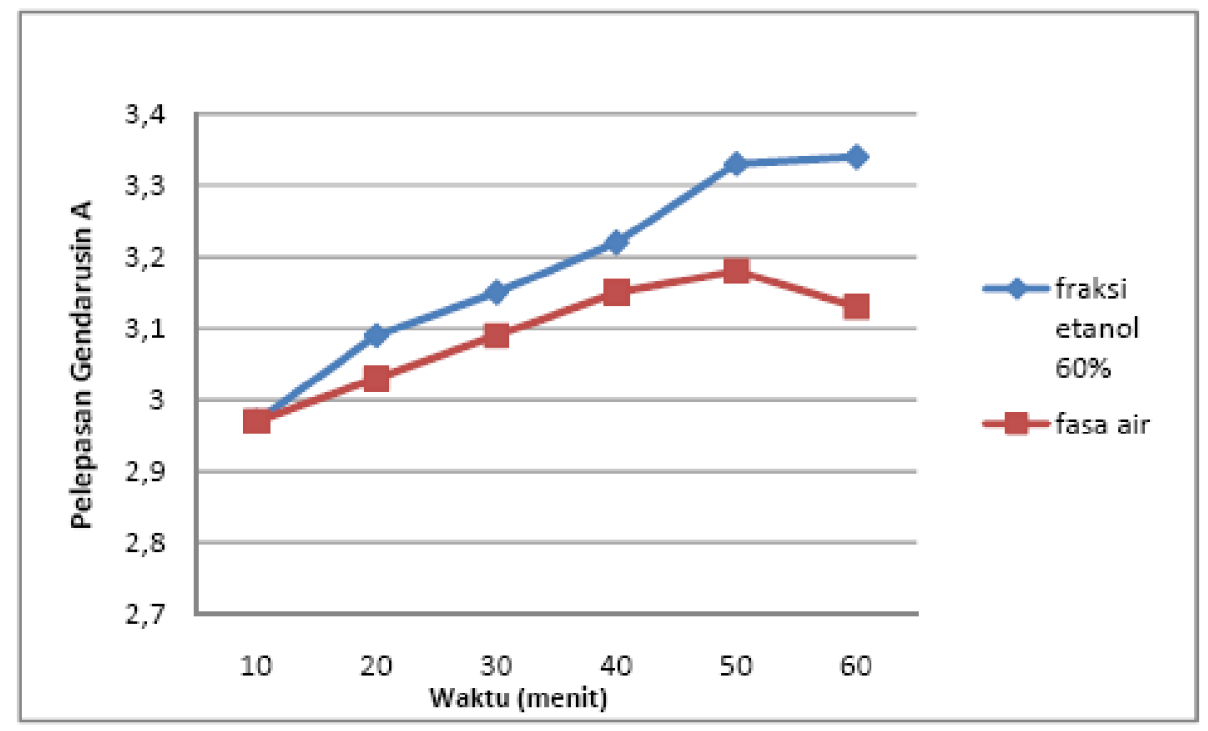

Gambar 1. Kurva Pelepasan Gendarusin A (\%)

kadar fraksi etanol 60\% dan kadar fasa air. Hasil penetapan kadar tertera pada Tabel 3 dan Tabel 4.

\section{Penentuan pH Sediaan Param}

Penentuan $\mathrm{pH}$ sediaan param tertera pada Tabel 5

\section{Uji Pelepasan}

Penetapan kadar Gendarusin A dari matriks param dilakukan dengan memasukkan area pada kurva baku standar dan didapatkan kadar, kemudian dihitung jumlah kumulatif Gendarusin A yang terlepas. Profil pelepasan Gendarusin A diperoleh dengan menggambarkan gendarusin A yang terlepas (Q) dalam cuplikan yang diambil pada tiap interval akar waktu tertentu.

Kecepatan pelepasan Gendarusin A (Fluks) diperoleh dari slope persamaan regresi masing-masing param dari 5menit sampai 25 menit antara $t \frac{1}{2}$ dengan jumlah kumulatif gendarusin A yang terlepas. Hasil dari percobaan ini : 
Persamaan regresi dari param fraksi etanol $60 \%$ :

Replikasi 1 :

$\mathrm{y}=0,5479 \mathrm{x}+101,1704, \mathrm{r}$ hitung $=0,9999$

$\mathrm{r}$ tabel $=0,811(\mathrm{a}=0,05, \mathrm{df}=\mathrm{n}-1)$

Replikasi 2 :

$\mathrm{y}=0,6650 \mathrm{x}+107,2109, \mathrm{r}$ hitung $=0,9747$

$\mathrm{r}$ tabel $=0,811(\mathrm{a}=0,05, \mathrm{df}=\mathrm{n}-1)$

Persamaan regresi dari param fasa air :

Replikasi 1 :

$\mathrm{y}=0,1766 \mathrm{x}+107,8448, \mathrm{r}$ hitung $=0,9878$

$\mathrm{r}$ tabel $=0,811(\mathrm{a}=0,05, \mathrm{df}=\mathrm{n}-1)$

Replikasi 2 :

$\mathrm{y}=0,6024 \mathrm{x}+106,5923, \mathrm{r}$ hitung $=0,9937$

$\mathrm{r}$ tabel $=0,811(\mathrm{a}=0,05, \mathrm{df}=\mathrm{n}-1)$

Untuk dapat melihat profil prosentase pelepasan gendarusin A dari param fraksi etanol $60 \%$ dan param fasa air dapat dilihat pada tabel serta gambar.

Dari hasil prosentase pelepasan gendarusin A rata-rata dari param fraksi etanol $60 \%$ dan param fasa air serta gambar 1 maka dapat dilihat yang memberikan pelepasan gendarusin A terbesar adalah param fraksi etanol $60 \%$. Sehingga untuk pemilihan bahan baku pembuatan param sebaiknya menggunakan fraksi etanol $60 \%$ karena proses ekstraksinya lebih pendek dari pada fasa air dan memberikan efek lebih cepat dibandingkan fasa air.

\section{KESIMPULAN DAN SARAN}

1. Kecepatan pelepasan gendarusin $\mathrm{A}$ dari sediaan param fraksi etanol $60 \%$ adalah $0,6065 \mu \mathrm{g} / \mathrm{cm}^{2} / \mathrm{menit}^{1 / 2}$ dan param fasa air adalah $0,3895 \mu \mathrm{g} / \mathrm{cm}^{2} /$ menit $^{1 / 2}$

2. Pelepasan gendarusin A dari param fraksi etanol $60 \%$ lebih besar dibandingkan param fasa air.

3. Dilakukan penelitian yang sama dengan waktu pengambilan sampel yang berbeda atau diperpanjang
4. Dilakukan penelitian dengan menggunakan bentuk sediaan farmasi yang lain

5. Dilakukan studi in vivo untuk melihat pelepasannya secara langsung dalam tubuh

\section{DAFTAR PUSTAKA}

Anonim, 1983, Toga (Tanaman Obat

Keluarga), Direktorat Pengawasan Obat Tradisional, Direktorat Jendral Pengawasan Obat dan Makanan, Dep

Kes RI, Jakarta, hal 4-5

Anonim, 1992, Semiloka Etik Penelitian

Obat Tradisional, Jakarta: Fakultas

Kedokteran Universitas Indonesia, hal 14

Anonim, 2002, The United State

Pharmacopoeia, 25Rd, Rockvielle :

United State Pharmacopoeial

Convention Inc, hal 2018

Anonim, 1999, Peraturan Perundang-

Undangan Di Bidang Obat

Tradisional, Direktorat Jendral

Pengawasan Obat dan Makanan departemen Kesehatan Republik Indonesia, Jakarta, hal 4

Ansel, HC, 1989, Pengantar Bentuk Sediaan Farmasi (terjemahan), ed

IV, UI press, Jakarta, hal 489-494

Backer, CA, RCB. Van Den Brink Jr, 1963,

Flora of Java, Vol II, The Auspices

Of The Rujkshet Barium, Leyden, hal 589

Barry W, Brian, 1983, Dermatological Formulation, Percutaneous Absorption, Marcel Dekker Inc, New York and Basel

Djoko H, 1995, Materia Medika Indonesia, Jilid IV, Depkes RI, Jakarta, hal 109-113

Elliott Middleton Jr, 1984. The Flavonoid, TIPS, hal 335-338 
Harborne, Jeffrey B at all, 1999, Phytochemical Dictionary, 2nd, Taylor and Francis 1td, London, hal 431

Hembing, WK.,AS Wirian, T Yaputra, S. Dalimartha dan B Wibowo, 1997, Tanaman Berkhasiat Obat Indonesia, Jilid I, ITB, Bandung, hal 44-45

Heyne K, 1987, Tumbuhan Berguna

Indonesia III, Badan Litbang

Kehutanan, Yayasan Sarana Wana Jaya, Hal 1759

Markham KR， 1988， Cara

Mengidentifikasi Flavonoid, ITB, Bandung, hal 1-7

Martin, Alfred at all, 1983, Physical Pharmacy (terjemahan), Lea and febiger, philadelphia, hal 827-897

Moeso, S dan Agus P, 1985, Laporan Perjalanan ke Jaya Pura Sentiani (Irian Jaya), Fakultas Biologi UGM, Yogyakarta, Hal 9

Mulja M dan Suharman, 1995, Analisis

Instrumental, Airlangga University

Press, Surabaya, hal 236-267

Oetari, S, 1986, Pengaruh Tipe Membran

Dan PH Cairan Penerima Terhadap

Difusi Asam Salisilat Secara In

Vitro, BPPS, Univ Gajah Mada, yogyakarta, hal 11

Prajogo B E W, 2002, Aktivitas

Antifertilitas Flavonoid Daun

Justicia gendarussa Burm.f : Penelitian Eksperimental

Pencegahan Penetrasi Spermatozoa Mencit Dalam Proses Fertilisasi In

Vitro, disertasi, Program Pascasarjana Universitas Airlangga, Surabaya

Prajogo B E W dan Suwijoyo Pramono, 1988, Isolasi glikosida Flavonoid dari daun Gendarusa (Justicia gendarussa Burm.f), simposium, Penelitian Tumbuhan Obat VI, Jakarta

Prasmawari, Santi, 2001, Uji Aktivitas Antiinflamasi Ekstrak Metanol Daun Gandarussa vulgaris Ness Pada Tikus Putih, Skripsi, Fakultas Farmasi Universitas Airlangga Surabaya

Reza, Shinta SA, 2004, Penetapan Kadar Gendarusin Dalam Fraksi Etanol $60 \%$ dan Fasa Air Daun Gendarussa vulgaris Nees Dengan Metode HPLC, Skripsi, Fakultas Farmasi Universitas Airlangga, Surabaya

Robinson, Trevor, 1983, The Organik Constituen of Higher Plants, 5th, Cordus Press, North Amrerst, hal 191 Sadono, 1999, Mekanisme Pelepasan Etil p-Metoksi Sinamat Pada Matriks Formula Param Beras Kencur, Laporan Penelitian Lemlit Unair, hal 1-15

Santoso, Singgih, 2003, Mengatasi

Berbagai Masalah Statistik Dengan SPSS Versi 11,5, PT Elex Media Komputindo, Jakarta, Hal 269-280

Setiawan, Dalimartha, 1999, Atlas

Tumbuhan Obat Indonesia, Jilid I, Trubus Asriwidya, Jakarta, hal 6164

Shargel, Leon dan Andrew BC, Yu, 1988, Biofarmasetika dan Farmakokinetika Terapan (Terjemahan), Ed II, Airlangga University Press, Surabaya, hal 85199

Van Stenis, C.G.G.J, 1987, Flora Untuk Sekolah di Indonesia, Pradya Paramita, Jakarta Pusat, Hal 393-414 